\title{
Seed source selection and genetic improvement of red oak (Quercus rubra L) in Québec
}

\author{
$J$ MacKay * \\ Direction de la recherche, Ministère des Forêts, 2700 rue Einstein, \\ Sainte-Foy (Québec), Canada, G1P 3 W8
}

\begin{abstract}
Summary - For reforestation of northern red oak (Quercus rubra $L$ ) in Québec, tested seed sources are not available. Seed zones have been delimited using eco-region boundaries, and seed collection areas and seed production stands have been selected within each zone. In some zones, however, high quality red oak stands are scarce. Provenance-progeny tests are therefore being established to deduce seed transfer rules and to delineate improvement zones, as well as to identify genetically superior materials for each zone. For long-term genetic improvement, the half-sib breeding population will be made up of sublines containing selected clones. Selection within the breeding population will emphasize traits that impact on tree form and sawlog quality, in addition to growth traits. Cuttings will be used to propagate selected clones and progeny in order to facilitate the rapid turnover of selected materials to reforestation.
\end{abstract}

provenance-progeny testing / half-sib breeding population / sublines / breeding zones / seed transfer

Résumé - Sélection génétique de sources de semences et amélioration du chêne rouge (Quercus rubra $L$ ) au Québec. Pour le reboisement du chêne rouge (Quercus rubra $L$ ) au Québec aucune source de semences recommandées n'a encore été identifiée. Des zones de récolte de semences ont été délimitées à partir des contours des régions écologiques. Des aires de récolte de semences et quelques peuplements semenciers ont été identifies mais les peuplements de chêne rouge de qualité sont toutefois rares dans certaines des zones de récolte. Des tests de provenances-descendances seront donc établis pour définir les limites de déplacement de semences, délimiter d'éventuelles zones d'amélioration et identifier pour chaque zone des sources de matériel génétiquement supérieures. Pour obtenir des gains soutenus à long terme, la population d'amélioration sera constituée de clones sélectionnés regroupés en lignées (sublines) et soumis à la pollinisation libre. La sélection dans cette population d'amélioration misera sur des facteurs qui influencent la forme des arbres et la qualité des grumes pour la production de bois d'œuvre, en plus de la croissance. Afin de rendre le matériel sélectionné disponible pour le reboisement plus rapidement, des clones et des descendances sélectionnés seront multipliés par bouturage.

test de provenances-descendances / population d'amélioration / lignées / zones d'amélioration / déplacement de semences

\footnotetext{
* Current address: Department of Forestry, PO Box 8002, North Carolina State University, Raleigh, NC 27695-8002, USA.
} 


\section{INTRODUCTION}

The natural range of red oak (Quercus rubra L) extends into the southern part of Québec where hardwood deciduous forests dominate. Past forest management practices, deforestation for agriculture and site limitations have restricted natural red oak regeneration in many parts of the range within Québec, leaving only scattered trees or small groups of trees in some areas. In the western part of Québec's deciduous forest, however, it is still abundant and thrives in large areas of rolling land. Nonetheless, local demand for quality red oak generally far surpasses the present supply, causing imports and reforestation of red oak to increase. The species appears to be well suited to our moderately acid soil types and well adapted to the cool climate. Reforestation of red oak has increased from a few thousand per year in the early 1980 s to 0.88 million projected for 1992.

Plantations will be aimed at the production of trees with high quality characteristics for lumber and veneer. Consequently, the quality of individual trees must be considered as being equally important as growth in the tree improvement program (Calvert, 1979). I outline here the strategy being used in Québec to 1) identify among existing seed sources (stands or mothertrees) those which show the best adaptation and growth traits to suit such needs; and 2) establish a breeding population which will generate genetically improved (multiclonal) varieties.

\section{SELECTION OF SEED SOURCES FOR REFORESTATION}

In the absence of tested seed sources, seed collection has begun in easily accessible stands. Eco-region boundaries were used as guidelines to establish tentative seed zones. Seed collection areas have been identified and seed production stands could be established within each of these zones. To date, only a few stands have actually been reserved and managed for seed production. It should also be possible for these stands to serve as populations for gene conservation purposes in addition to seed production (Namkoong, 1984).

In some eco-regions, however, natural stands with significant numbers of red oak are scarce. Moreover the quality of the few trees encountered in these regions generally appears to be questionable. It is therefore necessary to define seed transfer limits more precisely and to test the genetic quality of available seed sources in all ecoregions. Identification of well-adapted seed sources is especially critical, since the area considered is located at the northern limit of the species' natural range. This will be accomplished through a series of provenance-progeny tests which will include seed sources from the northeastern and north-central parts of the range and will be established on 6 sites spread across various eco-regions in southern Québec.

The structure of each test will allow for the determination of provenance as well as family effects. Each provenance will be represented by at least 5 half-sib families with maintained identities. Each test will be composed of a core group of half-sib families from a wide range of provenances repeated throughout all plantation sites. Exact repetition of the same genetically diverse families will aid in determining seed transfer limits and boundaries of improvement zones. A second group of families, varying in content from test-to-test, will mostly include families from the ecoregion in which the test is established. Due to uneven seed production between widespread areas and seed conservation difficulties, tests will be planted in 2 different years. Acorn collections were conducted in 
1990 and 1991. These collections overlap in composition to allow for statistical comparisons of all families.

\section{A TREE IMPROVEMENT STRATEGY FOR RED OAK}

Climatic adaptability and strong apical dominance, during the juvenile phase, are regarded as 2 key traits for producing trees with desirable form and quality characteristics (fig 1). Both climatic adaptability and apical dominance have an impact on several morphological traits, namely forking, branch angle and size, bole straightness and natural pruning ability. It has been suggested that tree morphology (ie, form) can be modulated through genetic improvement (Loretti and Pisani, 1990). However, traits related to tree morphology or form have received little attention in genetic studies of red oak. Various studies with other species have indicated the presence of significant levels of variation and genetic control for apical dominance and polycyclic growth (Teissier du Cros and Thiebault, 1988), branch angle (Merril and Mohn,
1985), and bole straightness (Williams and Lambeth, 1989). Provenance-progeny tests (as describe above) will be used to estimate the variation and heritabilities of these traits and the potential for improvement in red oak. Through results of these first provenance-progeny tests, selection criteria will be specified for the breeding population. Flushing date, for example (Kremer, 1986), could be used in genetic selection for spring frost resistance. It could also serve as an indicator for other traits like branch angle, as in Populus nigra (Teissier du Cros, 1977). Growth traits and wood properties, such as specific density, are also viewed as major areas for genetic improvement.

A half-sib breeding population divided into sublines (McKeand and Beineke, 1980; Coggeshall and Beineke, 1986) will be established using selected clones. This approach has the advantage of using inbred sublines while avoiding inbreeding at the seed orchard stage. At first, the entire range of red oak in Québec will be considered as a single breeding zone with 6 sublines, each containing 25-30 clones. The initial population could be subdivided if re-

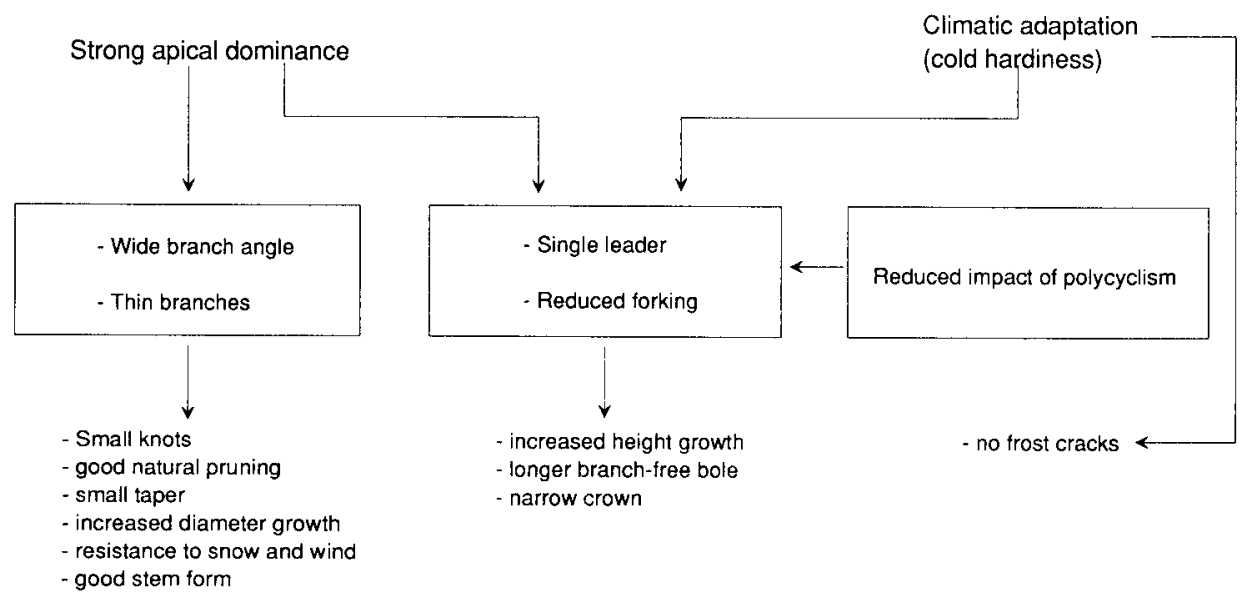

Fig 1. Impact of adaptability and apical dominance on tree form and tree quality (adapted from Karki, 1983). 
sults from provenance-progeny tests indicate that more than 1 breeding zone should be delineated. Additional sublines will then be established to maintain a minimum of at least 6 sublines/population.

Multiple-site progeny testing in the breeding population will be conducted in order to select the best families and progeny for second-generation sublines and for seed orchards. In the first generation(s), the selection emphasis will be placed on traits that influence tree quality and form directly (climatic adaptability, apical dominance, etc). With strongly inherited traits, gains should be sufficient so that selection weights can be reduced in following generations (Zobel and Talbert, 1984). In subsequent generations made up of materials with improved form, it is expected that gains in growth will be translated into more important (and more valuable) volume increases, as compared to trees with unimproved form. Alternative strategies based on index selection will also be considered.

To date, over 100 clones have been selected and grafted in Québec. These grafts will be used to establish 3 sublines in 1993, and 3 others are anticipated for 1994. Plus-tree selection was based primarily on climatic adaptation (absence of frost cracks) and tree form (apical dominance, reduced forking, branch angle and size, pruning ability and bole straightness). Trees selected ranged from 35 to 60 years of age, because observation of form is most practical and meaningful at that development stage (Beineke, 1979).

As suggested by Coggeshall (1987), clonal propagation using cuttings will be employed to multiply progeny obtained in the breeding population for increased precision during testing. Large-scale cutting operations could also be implemented to produce propagules for reforestation from selected material before seed orchards can be established.

\section{ACKNOWLEDGMENTS}

The author acknowledges the technical assistance of $P$ Lortie and critical comments of $M$ Villeneuve, A Rainville, $Y$ Lamontagne, $R$ Beaudoin, A Stipanicic and $C$ Beaulieu in the planning of this work and for reviewing this manuscript.

\section{REFERENCES}

Beineke WF (1979) Tree improvement in the oaks. Proceedings of the 1979 John S Wright Conference: Regenerating Oaks in Upland Hardwood Forests, Purdue University, West Lafayette IN, 126-132

Calvert RF (1979) Status of hardwood tree improvement. Proceedings of the CanadaOntario Joint Forestry Research Committee Symposium, Great Lakes Forest Research Centre O-P-7, 161-166

Coggeshall MV (1987) New approaches to northern red oak improvement in Indiana. 5th NCFTIC, Fargo, ND, 24-33

Coggeshall MV, Beineke WF (1986) The use of multiple breeding populations to improve northern red oak (Quercus rubra $\mathrm{L}$ ) in Indiana. IUFRO Joint Meeting of Working parties on Breeding Theory, Progeny Testing and Seed Orchards, Williamsburg VA, 540-546

Karki $L$ (1983) The Foundation for Forest Tree Breeding in Finland. Information Bulletin 1/ 1983

Kremer A (1986) Le chêne rouge d'Amérique. Rev For Fr (special issue) 165-167

Loretti F, Pisani P (1990) Structural manipulation for improved performance in woody plants. Hortscience 25, 64-70

McKeand E, Beineke WF (1980) Sublining for half-sib breeding populations of forest trees. Silvae Genet 29, 14-17

Merrill RE, Mohn CA (1984) Heritability and genetic correlations for stem diameter and branch characteristics in white spruce. Can J For Res 15, 494-497

Namkoong G (1984) A control concept of gene conservation. Silvae Genet 33, 4-5

Teissier Du Cros E (1977) Aperçu de la transmission héréditaire de quelques caractères 
juvéniles chez Populus nigra L. Ann Sci For 34, 311-322

Teissier Du Cros E, Thiebault B (1988) Variability in beech: budding, height growth and tree form. Ann Sci For 45, 383-398
Williams CG, Lambeth CC (1989) Bole straightness measurement for advanced generation loblolly pine genetic tests. Silvae Genet 38, 212-217

Zobel B, Talbert J (1984) Applied Forest Tree Improvement. John Wiley \& Sons, New York 